\title{
Doğu ve Güneydoğu Anadolu Bölgelerinde Eğitim ve Öğretim (1923-1938)
}

\author{
Bahattin DEMIRTAŞ
}

\section{ÖZET}

Millî Mücadelenin kazanılması ve Türkiye Cumhuriyeti'nin kurulmasından sonra Osmanl Devleti Döneminde başlayan, ancak yarım ve eksik kalan yenilik hareketlerine devam edilmiştir. Böylece Mustafa Kemal Atatürk'ün öncülüğünde gerçekleştirilen modernleşme çabaları eğitim başta olmak üzere birçok alanda kendini göstermiştir. Eğitimde Tevhid-i Tedrisat ile başlayan bu inkzlâp hareketi ilk ve ortaöğretimden, üniversite eğitimine kadar planll olarak eğitimin her kademesinde gerçekleştirilmiştir. 1923-1938 yılları arasıın kapsayan bu çalışmada, Türkiye'nin genel eğitim politikalarından ziyade arşiv belgeleri ve istatistiki verilerin desteğinde Doğu ve Güneydoğu Anadolu vilayetlerinin eğitim durumu yansıtılmaya çalışılacaktır. Ögrenci.

Anahtar Kelimeler: Doğu ve Güneydoğu Anadolu, Eğitim, Okul, Öğretmen,

\section{Education in the Eastern and South-Eastern Anatolia}

$$
\text { (1923-1938) }
$$

\section{ABSTRACT}

After achieve of Turkish National struggle and found of Turkish Republic, reform movements which began in Ottaman State period but incompleted were contiuned. Therefore, the modernization movements, particularly on education, have increasingly continued with the leadership of Mustaf Kemal Atatürk. To began with Tevhid-i Tedrisat in education, this revolutions movements, from primary and second school to university education planned every step of education were realized.

* Gazi Úniversitesi, Gazi Eğitim Fakültesi, Tarih Eğitimi Anabilim Dalı, bdemirtas@gazi.edu.tr 
In this study, comprising the period of 1923-1938, the educational state of the regions of Eastern and South-Eastern Anatolia will be reflected in the light of the documentaries and statistical data.

Key Words: Eastern and South-Eastern Anatolia, Education, School, Teacher, Student.

\section{GİRIŞ}

Osmanlı Devletinde eğitim faaliyetleri uzun yıllar vakıflar tarafından desteklenen medrese ve tekkeler aracılığıyla gerçekleștirilmiştir. Tarih içinde birer ekonomi ve kültür merkezi konumunda olan Doğu ve Güneydoğu Anadolu $^{1}$ vilayetlerinde medreseleri ve bugünün ilkokulları olan Sibyan mekteplerini, Tanzimat ve Meşrutiyet dönemi yenilik hareketleri ile birlikte açılan Rüştiyeler, İdadiler, İptidai mektepler, Darü'l-muallimler ve Sultaniler izlemiştir. Müslüman ve gayrimüslim halkın eğitim aldığı bu ilk ve ortaöğretim kurumlarının yanında, XIX. yy.dan itibaren Elazığ, Gaziantep, Bitlis, Kars, Erzurum gibi vilayetlerde Ermeni, Alman, Amerikan ve Fransız misyoner okullarının açıldığı görülmüştür.

Doğu ve Güneydoğu Anadolu Bölgesi çoğunlukla eğitim kurumlarının, öğrenci ve öğretmenlerin nitel ve nicel durumları açısından Türkiye ortalamalarının altında kalmaktadır. Bu duruma gerek Osmanlı Devleti gerekse Türkiye Cumhuriyeti döneminde neden olan bazı genel ve bölgesel durumlar vardır. Osmanlı Devletinde ilmiye sınıfının gerilemesi, eğitimde millî ve çağdaş bir seviyenin yakalanamaması, eğitim kurumlarında dini ilimlerin pozitif ilimlerden daha fazla yer tutması, bölgenin Birinci Dünya Savaşı ve Millî Mücadele yıllarında işgali, işgallerin getirdiği yıkım ve göç, savaşın asker ihtiyacının bir bölümünün ortaöğretim düzeyindeki okullardan karşılanması, bu savaş yıllarında yaşanan kıtlık ve salgın hastalıklar, cumhuriyet sonrasında bölgede çıkan isyanlar ve zaman zaman yaşanan deprem gibi tabii afetler, Doğu ve Güneydoğu Anadolu'da eğitimin kurumlaşması ve yaygınlaşmasını engellemiştir.

Eğitimde bütün bu engelleyici durumlara rağmen Cumhuriyet'in ilan edilmesi, Tevhid-i Tedrisat Kanunu ve Tekke ve Zaviyelerin kapatılması ve

'Toplumsal ve ekonomik yapı bakımından benzer özellikleri sebebiyle "Doğu Bölgesi" olarak adlandırılan Doğu ve Güneydoğu Anadolu Bölgesinin sınırları hakkında değişik görüșler bulunmakla birlikte burada coğrafi bakımdan yapılan sımırlandırma esas alınacaktır. Buna göre Doğu Anadolu Bölgesi'ne Ağn, Bingöl, Bitlis, Elazığ, Erzincan, Erzurum, Hakkâri, Kars, Malatya, Muş, Tunceli ve Van, Güneydoğu Anadolu'ya ise Adiyaman, Diyarbakır, Gaziantep, Mardin, Siirt ve Urfa illeri dâhil olmaktadır. Konuya coğrafi bölge olarak Akdeniz'de yer alan Kahramanmaraş ili de ilave edilebilmektedir. Böylece çalışmada incelenen dönemin idari yapılanmasına dikkat edilmiş ve sonradan il olan yerler eski bağlı olduklan vilayetlerle ele alınmışlardır. 
Türkiye'de laik eğitime geçilmesiyle birlikte tüm ülkede olduğu gibi Doğu ve Güneydoğu Anadolu Bölgelerinde de yeniden bir toparlanma ve çağdaşlaşma hamlesi yaşanmaya başlamıştır. Atatürk inkılâpları olarak gördüğümüz ve hemen hemen her sahada başlayan yenilikler özellikle eğitim alanında kendini göstermiştir ${ }^{2}$. Böylece 29 Ekim 1923 y1lında kurulan yeni Türk devleti, bölgesel farklılık göstermeden ve dönemin imkânları çerçevesinde ülkenin genel, Doğu ve Güneydoğu Anadolu'nun özel eğitim faaliyetlerini düzenlemeye yönelik adımlar atmıştır. $\mathrm{Bu}$ faaliyetler, doğu bölgesindeki okullaşma oranını artırma, artan öğrenci sayısı karşısında ögretmen ihtiyacını karşılama ve eğitimin maddi gereksinimlerini olabildiğince giderme amacına yönelik olmuştur.

\section{A.Bölgede İlk ve Ortaöğretimdeki Gelişmeler}

Cumhuriyet ilan edildiği yıl Türkiye'nin nüfusu 11-12 milyon idi. Bu nüfusun $\% 10$ 'u ve kadınların ise sadece \%3'ü okuryazardı. Ülkede 4.894 ilkokul, 72 ortaokul, 23 lise, 64 meslek okulu, 9 fakülte ve yüksek okul, yani toplam 5.062 eğitim-öğretim kurumu vard. İlkokullarda 341.941, ortaokullarda 5.905, liselerde 1.241, meslek okullarında 6.547 ve yüksek öğretimde 2.914, olmak üzere toplam 358.548 öğrenci vard. ${ }^{3}$ Bu olumsuz tabloyu Mustafa Kemal Atatürk şöyle yorumlamıştır: "Uzun asırların uysusturucu idare ve terbiyesinin, bir heyet-i içtimaiyeyi, bir günde, bir senede azat edebileceğini tasavvur ve kabul etmek doğru değildir." ${ }^{\text {"4 }}$ Okullara ve bu okullarda okuyacak genç nesillere büyük önem veren Atatürk'ün eğitimle ilgili işlerde oldukça hassas davrandığı görülmektedir. Ona göre eğitim millî́, laik, demokratik ve çağdaş özellikleri ile yaygınlaștırılmalıdır. Zira onun gerek başbakanları ve millî eğitim bakanları gerekse öğretmen ve öğrencilerle olan görüşme ve konuşmalarında bu net olarak görülebilmektedir. Atatürk'ün eğitime verdiği önem dolayısıyla ülkenin her yerinde bir eğitim seferberliği hali yaşanmıştır.

${ }^{2}$ Cumhuriyet döneminde ki bölgesel eğitim gelişmelerinden önce Osmanlı Devleti döneminde eğitim ve öğretiminde bölgesel uygulamalarda vardır. Örneğin, II. Abdülhamid döneminde siyasi, dini ve idari amaçlarla ilk önce Arap aşiret çocuklarına mahsus olmak üzere açılan sonraları Arnavutluk ve Doğu Anadolu'daki aşiretlerden de öğrenci kabul edilen Aşiret Mektepleri özel bir durumdur. Ancak merkezi otoriteyi kuvvetlendirmek ve mahalli otoriterlerin itaatini, saltanat ve hilâfete bağlılığını sağlamaya yönelik bu okullar istenilen faydayı getirmeyecektir.

${ }_{3}$ Yahya Akyüz, Türk Eğitim Tarihi, Ankara, Pegem Yayıncılık, 2006, s.346 vd.

${ }^{4}$ Enver Ziya Karal, Atatürk'ten Düssünceler, Ankara, ODTÜ Gelişme Vakfi Yayıncılık ve Iletiş̧im, 1998, s.62.

Atatürk'ün eğitimin millî ve çăgdaș olması gerekliliği Ziya Gökalp'te de görülmektedir. Gökalp’e göre eğitim millî olduğu gün, ister istemez modern de olacaktır. Eğitimin bir amacı da millî bireyler yetiştirmektir. Çünkü bu özellikteki kişiler ulus topluluğunun seçkin sınıfını meydana getirirler. Ziya Gökalp, Milli Terbiye ve Maarif Meselesi, Ankara, 1972, s.134-135 ;Ziya Gökalp, Terbiyenin Sosyal ve Kültürel Temelleri, İstanbul, Millî Eğitim Basımevi, 1973. 
Eğitimle ilgili gelişmelerin sonuçları Ankara'ya iletilirken ilk başlarda ülke genelinde ve doğu bölgelerinde eğitim ve öğretim işlerine ait raporlar çok da olumlu değildir. Ancak cumhuriyet döneminde her şeye rağmen mücadeleye devam edilecektir. Doğu ve Güneydoğu Anadolu'daki eğitime ait bu ilk raporlar bizzat Atatürk'ün direktifleriyle kurulmuş olan birimlerden gelmiştir. Burada en önemli sorun maarif namına çok az şey olduğudur. Mesela MAH'n ${ }^{6} 5$ Nisan 1928 tarihinde verdiği bir raporda "Urfa vilayetinde doğru dürüst okul olmadığı" belirtilirken, yine MAH'ın başbakanlığa 4068 numara ve 8 Nisan 1928 tarih ile sunduğu raporunda "Maarif hemen hemen Hakkâri vilayetinde yok gibidir" denilmektedir. Ayn raporlarda bölgede okul çağındaki genç ve çocukların okullardan istifade nispetlerinin çok düşük olduğu aktarılmaktadır. Elazığ Valiliğinin raporundaki şu yüzdeler de oldukça çarpıcıdır: "3.544 ilkokula, 300 civarında da ortaokula devam eden ögrenci vardır. Hâlbuki vilayet dâhilinde tahsil çağındaki ögrenci miktan 30.000'den fazladır. İlkokuldan istifade nispeti \%12 civarindadır." 7

MAH'ın doğu bölgesindeki eğitim meselelerini ele alan raporlarından başka Başbakan İsmet İnönü'nün Kürt raporu konuya ait başka bir kaynak olmuştur. İsmet İnönü'nün 1935 yılında hazırlayıp Atatürk'e sunduğu raporda, Doğu ve Güneydoğu Anadolu vilayetlerinin imar, iskan, sağlık, güvenlik durumlarına yer verilmiştir. İnönü, raporunda gezip gördüğü yerlerde edindiği izlenimler doğrultusunda eğitim ve kültür meselesine de büyük önem verilmesi gerektiğini belirtmiş ve eğitimle ilgili şu bilgilere yer vermiştir: "Kürtlere okutma yapılıp yapılmayacağı şimdiye kadar bir politika olarak mütalaa edilmiştir. Bu politikay halk biliyor. Biz bundan hiç istifade edemediğimiz halde yalnız mahzurunu çekiyoruz. Daha Türk köylerindeki mektepleri yapamamışken ve en nihayet ona varmayan okutmada bir hususi siyasay halkın diline düşürmekte hiçbir fayda yoktur. Sonra ilk tahsil için okutmakta faydamızın daha siyasi olduğu görüşündeyim. Kürtleşmiş ve kolayca Türklüğe dönecek yerleri okutmak, hatta Kürtlere Türkçe ögrreterek Türklüğe çekmek için ilk tahsil ve onun iyi hocası çok etkili vasitadır. Zaten sınırlı olan vasitalarımızı daha çok Türk köylerinde kullanmak elimizdedir." 8

${ }^{6}$ Millî Emniyet Hizmeti Riyâseti (Bundan sonra MAH olarak kısaltılacaktır): 6 Ocak 1926 tarihinde kurulan ve cumhuriyetin ilk istihbarat teşkilatı olan Millî Emniyet Hizmeti Riyasetinin kısaltmasıdır. Bu birim 06 Temmuz 1965 tarihli kanunu ile başbakanlığa bağlı olan Millî İstihbarat Teşkilatına (MIT) dönüştürülmüştür.

Hamit Pehlivanl, "Cumhuriyet'in flk Ylllarından Günümüze Doğu ve Güneydoğu Anadolu'nun Meseleleri: Örnek Raporlar Işığında Karşılastırmalı Bir Inceleme", Besinci Askeri Tarih Semineri Bildirileri (Istanbul 1995), Ankara 1996, s.557-559. Elazığ Valiliğine ait raporun tarihi yazar tarafindan belirtilmemiştir.

${ }^{8}$ Saygı Öztürk, Ismet Paşa'nın Kürt Raporu, Istanbul, Doğan Kitap, 2007, s.62-63. 
İsmet İnönü'nün raporundan sonra Bitlis, Diyarbakır, Van, Hakkari, Muş, Mardin, Urfa, Siirt vilayetlerini kapsayan Birinci Umumi Müfettişliği 'ne Abidin Özmen atanmıştır. Özmen, Güneydoğu'ya ayrı bir önem veren hükümete müfettişlik bölgesinin iç siyasal durumunu anlatan ayrıntılı bir rapor hazırlamıștır. Raporda, bölge insanının Türkçe ile konuşur hale getirilmesi ve köy çocuklarının kurulacak yatılı okullarda eğitim görmesinin gerekliliği ile eğitim meselesine yönelik tedbirler ele alınmaya başlamıștır. Müfettişlik bölgesinde açılacak okulların geniş binalı, hastanesi, eczanesi yerinde müstakil veya tez uğrayan bir doktorun kontrolünde, yetișmiş, azimli, çalıșkan öğretmenlerin idaresinde olması istenmiștir. Bu okullarda başta Türkçe konuşmayı sevdirecek kapsamlı bir program ile üç yıllık öğrenim verilecektir. Ancak okullar kaza ve bazı nahiye merkezlerinde genel beş yıllık okullara engel olmayacaktır. Rapor şu cümlelerle devam etmektedir: "Bugün vilayetlerin bütçeleriyle ancak kazalarda ve bazı nahiyelerde çok sinırl köylerde üç sinıfi okutan ögretmenlerle idare edilebilmektedir. Büyük Türk köylerinde de beş sintfl program üzerine kurulu okulların varliğı kabul edilebileceğine göre vilayetlerin zirai, veteriner birçok işleri kanuni, idari ve içtimai birçok yardımları bırakmadan parasız okul meydana getirmelerine maddeten imkân görüyorum. Hükümetçe seneden seneye bir program altında uygun yerlerden başlayarak böyle müesseseler kurmak gerekiyor. Böyle müesseseler ilk olarak Van'ın Gevaş, Hakkari'nin Beytüşşebap, Bitlis 'in Hizan, Muş'un Malazgirt, Siirt'in Pervari, Diyerbekir'in Şerbati, Urfa'nın Viranşehir kazalarında kurulabilir. ${ }^{, 10}$

Eğitimle ilgili raporlarla birlikte incelenen istatistikî bilgiler ışı̆̆ında, 1923-1928 yılları arasında doğudaki bazı vilayetlere ait nüfusun cinsiyete göre okuma yazma oranını ve okul durumunu gösteren veriler elde edilebilmektedir.

${ }^{9}$ Umumi Müfettişlik uygulaması Osmanlı idari sisteminin bir mirası olup yakın tarihimizde Doğu ve Güneydoğu Anadolu Bölgesinde denenmis olan Olağanüstü Hal Bölge Valiliği uygulamasına benzemektedir. Cumhuriyet döneminde ilk Umumi Müfettişlikler 25 Haziran 1927 tarihinde TBMM tarafından kabul edilen Birinci Umumi Müfettişlik Teşkiline Dair Kanun ile kurulmuştur. Bu konuda bkz. Cemil Koçak, Umumi Müfettişlikler (19271952), Istanbul, fletişim Yayınları, 2003, s.54 vd.

${ }^{0}$ S.Öztürk, a.g.e., s.79-80. 
Tablo 1. Vilâyetlere Göre Nüfusun Tahsil ve Okul Durumu $(1928)^{11}$

\begin{tabular}{|c|c|c|c|c|}
\hline Vilâyetler & Cinsiyet & $\begin{array}{l}\text { Okuma } \\
\text { Bilen \% }\end{array}$ & $\begin{array}{l}\text { Okuma } \\
\text { Bilmeyen \% }\end{array}$ & $\begin{array}{l}\text { Okul } \\
\text { Sayısı }\end{array}$ \\
\hline \multirow[b]{2}{*}{ Bayazıt(Ağrı) } & $E$ & 4.52 & 95.48 & \multirow[b]{2}{*}{21} \\
\hline & $\overline{\mathrm{K}}$ & 0.18 & 99.82 & \\
\hline \multirow[b]{2}{*}{ Bitlis } & $\mathrm{E}$ & 3.31 & 96.69 & \multirow[b]{2}{*}{25} \\
\hline & $\mathrm{K}$ & 0.10 & 99.90 & \\
\hline \multirow[b]{2}{*}{ Diyarbakır } & $\mathrm{E}$ & 5.86 & 94.14 & \multirow[b]{2}{*}{19} \\
\hline & $\mathrm{K}$ & 1.03 & 98.97 & \\
\hline \multirow[b]{2}{*}{ Elazığ } & $\bar{E}$ & 7.70 & 92.30 & \multirow[b]{2}{*}{74} \\
\hline & $\overline{\mathrm{K}}$ & 0.70 & 99.30 & \\
\hline \multirow[b]{2}{*}{ Erzincan } & E & 9.39 & 90.61 & \multirow[b]{2}{*}{87} \\
\hline & $\mathrm{K}$ & 1.57 & 98.43 & \\
\hline \multirow[b]{2}{*}{ Erzurum } & $\bar{E}$ & 6.82 & 93.18 & \multirow[b]{2}{*}{139} \\
\hline & $\mathrm{K}$ & 0.82 & 99.18 & \\
\hline \multirow[b]{2}{*}{ Gaziantep } & $E$ & 7.72 & 92.28 & \multirow[b]{2}{*}{85} \\
\hline & $\mathrm{K}$ & 1.58 & 98.42 & \\
\hline \multirow[b]{2}{*}{ Hakkâri } & $\mathrm{E}$ & 2.28 & 97.72 & \multirow[b]{2}{*}{2} \\
\hline & $\overline{\mathrm{K}}$ & 0.38 & 99.62 & \\
\hline \multirow[b]{2}{*}{ Kars } & $\mathrm{E}$ & 4.69 & 95.31 & \multirow[b]{2}{*}{63} \\
\hline & $\mathrm{K}$ & 0.81 & 99.19 & \\
\hline \multirow[b]{2}{*}{ Malatya } & $\mathrm{E}$ & 6.35 & 93.65 & \multirow[b]{2}{*}{117} \\
\hline & $\bar{K}$ & 0.82 & 99.18 & \\
\hline \multirow[b]{2}{*}{ Maraș } & $\mathrm{E}$ & 4.38 & 93.62 & \multirow[b]{2}{*}{57} \\
\hline & $\mathrm{K}$ & 0.80 & 99.20 & \\
\hline \multirow[b]{2}{*}{ Mardin } & $\mathrm{E}$ & 4.05 & 95.95 & \multirow[b]{2}{*}{19} \\
\hline & $\mathrm{K}$ & 0.34 & 99.66 & \\
\hline \multirow[b]{2}{*}{ Siirt } & $E$ & 6.66 & 93.34 & \multirow[b]{2}{*}{17} \\
\hline & $\mathrm{K}$ & 0.29 & 99.71 & \\
\hline \multirow[b]{2}{*}{ Urfa } & $E$ & 5.28 & 94.72 & \multirow[b]{2}{*}{28} \\
\hline & $\mathrm{K}$ & 0.61 & 99.39 & \\
\hline \multirow[b]{2}{*}{ Van } & $E$ & 2.39 & 97.61 & \multirow[b]{2}{*}{24} \\
\hline & $\mathrm{K}$ & 0.12 & 99.88 & \\
\hline
\end{tabular}

E: Erkek K: Kadin

Tabloya göre, cumhuriyetin ilk yıllarında okullaşma açısından Hakkâri sonuncu sırada yer alırken, Erzurum 139 okulla birinci sırada bulunmaktadır. Okul oranının bölge ortalamasından yüksek olduğu diğer iki il Erzincan ve Malatya'dır. Tabloda dikkat çeken diğer bir durum, Harf inkılâbının henüz gerçekleşmediği bu dönemde bölgedeki okur-yazar kadın ve erkek oranının Türkiye ortalamasının altında olduğudur. Ayrıca vilâyetlerin tümünde erkeklerin okur-yazarlık oranının kadınlardan fazla olduğudur. Bu ise bölgedeki sosyal yapının yani kız çocuklarını okula göndermeme geleneğinin bir göstergesidir. Günümüzde dahi bölgede okula giden kız ögrenci sayısının az olduğu göz önünde bulundurulduğunda bu durumun eskiden beri süre geldiği anlaşılmaktadır. 1923-1938 yılları arasında

${ }^{11}$ Devlet Istatistik Enstitüsü (Bundan sonra DIE olarak kısaltılacaktır), Istatistik Yıllığı, c. 2, Y1l: 1929, s.30-37. 
vilayetler arasında erkek nüfusta okuma-yazma oranının en fazla olduğu yer Erzincan'dır. Bu şehirde okuma bilmeyen erkeklerin oranı \%90.61'dir. Okuma-yazma bilen kadınların en yoğun olduğu vilayetler ise Gaziantep ve Erzincan'dır. Buna rağmen Gaziantep'te okuma bilmeyen kadınların oranı $\% 98.42$ gibi hiç de düşük olmayan bir rakamdadır.

Tablo 2. Vilayetlere Göre Ilkokullar ve Bunların Öğretmen ve Öğrenci Miktarı

\begin{tabular}{|c|c|c|c|c|}
\hline Vilayetler & Seneler & Okul & Ōğretmen & Öğrenci \\
\hline \multirow[t]{2}{*}{ Ağrı } & $1929-1930$ & 13 & 30 & 858 \\
\hline & $1936-1937$ & 17 & 37 & 1.343 \\
\hline \multirow[t]{2}{*}{ Bitlis } & $1929-1930$ & $*_{-}$ & - & - \\
\hline & $1936-1937$ & 11 & 26 & 875 \\
\hline \multirow[t]{2}{*}{ Bingöl } & $1929-1930$ & $*_{-}$ & - & - \\
\hline & $1936-1937$ & 8 & 14 & 553 \\
\hline \multirow[t]{2}{*}{ Diyarbakır } & $1929-1930$ & $*_{-}$ & - & - \\
\hline & $1936-1937$ & 23 & 84 & 3.098 \\
\hline \multirow[t]{2}{*}{ Elazığ } & $1929-1930$ & 64 & 128 & 3.050 \\
\hline & $1936-1937$ & 35 & 87 & 3.799 \\
\hline \multirow[t]{2}{*}{ Erzincan } & $1929-1930$ & 67 & 107 & 4.167 \\
\hline & $1936-1937$ & 34 & 78 & 3.689 \\
\hline \multirow[t]{2}{*}{ Erzurum $^{15}$} & $1929-1930$ & 82 & 154 & 6.830 \\
\hline & $1936-1937$ & 98 & 195 & 7.845 \\
\hline \multirow[t]{2}{*}{ Gaziantep } & $1929-1930$ & 62 & 142 & 3.696 \\
\hline & $1936-1937$ & 71 & 169 & 7.698 \\
\hline \multirow[t]{2}{*}{ Hakkâri } & $1929-1930$ & 2 & 2 & 44 \\
\hline & $1936-1937$ & 3 & 6 & 155 \\
\hline \multirow[t]{2}{*}{ Kars } & $1929-1930$ & 89 & 133 & 5.119 \\
\hline & $1936-1937$ & 81 & 159 & 8.144 \\
\hline \multirow[t]{2}{*}{ Mardin } & $1929-1930$ & 18 & 50 & 1.365 \\
\hline & $1936-1937$ & 28 & 60 & 2.361 \\
\hline \multirow[t]{2}{*}{ Maraş } & $1929-1930$ & 45 & 90 & 3.035 \\
\hline & $1936-1937$ & 44 & 92 & 4.507 \\
\hline \multirow[t]{2}{*}{ Muș } & $1929-1930$ & 12 & 26 & 496 \\
\hline & $1936-1937$ & 6 & 17 & 539 \\
\hline \multirow{2}{*}{ Siirt } & $1929-1930$ & 10 & 22 & 421 \\
\hline & $1936-1937$ & 14 & 37 & 970 \\
\hline \multirow[t]{2}{*}{ Malatya } & $1929-1930$ & 111 & 215 & 6.032 \\
\hline & $1936-1937$ & 99 & 192 & 9.912 \\
\hline Urfa & $1929-1930$ & 35 & 103 & 8.023 \\
\hline
\end{tabular}

${ }^{12}$ Başbakanlık Cumhuriyet Arşivi (Bundan sonra BCA olarak kısaltılacaktır): Fon Kodu: 030.01./90.559.2 ; DIE, Istatistik Yıllığı, c.5, Yıl: 1931-1932.

${ }^{13} 1935$ yilında bir belgede Erzurum'da nerelerde kaç okul ve bu okulların her birinde kaç öğretmen ve öğrenci bulunduğunu, bu okullardan kaç öğrenci mezun olduğunu ayrıntılı olarak gösteren bilgiler yer almaktadır. Belgeye göre vilayette muvazenei umumiyeye dâhil bir lise, bir erkek muallim ve bir kız orta ve muvazenei hususiyeye dâhil 17 tam devreli ve 79 birinci devreli olmak üzere 96 ilkokul vardır. 1935 yılında lisenin 24 muallimi, 537 öğrencisi ve 20 mezunu vardır. Erkek muallimin 10 muallimi, 99 öğrencisi, 24 mezunu vardır. Kız ortanın, 8 muallimi, 79 okuru, 11 muzunu vardır. 17 tam devreli ilkokulun 99 muallimi, 3373 öğrencisi, 282 mezunu vardır. Birinci devreli 79 ilkokulun 80 muallimi, 3.462 öğrencisi, 425 mezunu vardır. Toplam muallim 221 , öğrenci 7.750 ve mezun 762 'dir. $B C A$ : 15.07 .1935 , Fon Kodu: $30.10 . / 65.433 .1$. 


\begin{tabular}{|l|l|l|l|l|}
\hline & $1936-1937$ & 31 & 95 & 3.374 \\
\hline Van & $1929-1930$ & 11 & 27 & 644 \\
\hline & $1936-1937$ & 12 & 36 & 1.201 \\
\hline \multicolumn{2}{|c|}{ Toplam (1929-1930) } & 621 & 1.229 & 43.780 \\
\hline Toplam (1936-1937) & 596 & 1.260 & 55.537 \\
\hline Türkiye Toplam(1936-1937) & 6.123 & 14.698 & 711.728 \\
\hline
\end{tabular}

* Malumat yoktur (Bölgesel toplamlarda bu yerler hesaba dâhil edilmemiştir).

Bölgeye ait ilk, orta ve lise düzeyindeki okulların sayısı, buradaki öğrenci ve öğretmen miktarlarını gösteren istatistikî bilgiler bulunmaktadır. Bu bilgiler dâhilinde senelere göre eğitimde gerçekleşen sayısal gelişmeyi görmek mümkün olabilmektedir. Bu amaçla bölgede ilk olarak, tablo 2'de görüldüğü gibi, ilkokul düzeyindeki okullara ait veriler incelenmiştir. Buna göre; ilkokulların 1929-1937 yılları arasındaki artışının vilayetler itibariyle çok fazla olmadığı görülmektedir. 1937'de Ağrı, Erzurum, Gaziantep, Mardin, Hakkari, Siirt, Van sekiz yıl öncesine göre okul sayısının arttığı vilayetler olurken, Elazığ, Erzincan, Kars, Maraş, Muş, Malatya ve Urfa'da tersi bir durum yaşanmıştır.

1929 ve 1937 yıllarında ögretmen sayısı da okul ve öğrenci toplamına göre yetersizdir. Hakkâri, Ağrı, Van okul ve öğretmen bakımından bölgenin en düşük verilerini taşırken; Malatya, Erzurum ve Kars bu bakımdan bölge ortalamalarının üzerindedir.

Tablo 2'ye göre, okul sayıları azalan vilayetlerde (Kars ve Maraş hariç), öğretmen sayısında da bir azalma yaşanmıştır. Ancak, vilayetlerin ilkokul öğrenci sayısı, okul sayısındaki azalmalara (Erzincan hariç) veya bazı vilayetlerdeki okullaşmadaki artış oranının düşük olmasına rağmen bariz olarak artmıştır. Örneğin Kars'ta 1929'da 89 olan ilkokul sayısı, 1937'de 81 'e düşmesine rağmen bu vilayetteki öğrenci sayısı 5.119'dan 8.144'e çıkmıştır. Siirt'te ise, sekiz yıllık sürede 10 'dan 14 'e çıkan ilkokul sayısına rağmen, bu dönemde öğrenci sayısı 421 'den 970 'e çıkmıştır. Yani \%100'den daha fazla bir artış gerçekleşmiştir.

Cumhuriyet ilan edildiğinde tüm Türkiye'de olduğu gibi doğu bölgesinde de ortaöğretim seviyesindeki durum, ilkokullara göre çok daha yetersizdir. Bu durumun düzelmesi uzun yıllar alacaktır. Nitekim 1927-1928 eğitim-öğretim yılında ilkokulların dışında Türkiye'de 71 ortaokul varken, 1935-1936 öğretim yılında bu sayının hâlâ 100 'de kalması doğu illerinde açılabilen ortaokul sayısının çok az olduğuna işarettir. Tablo 3 'de görüldüğg̈ gibi 1936-1937 öğretim yılında ortaokulu olan doğu vilayetleri ve bu vilayetlerdeki okul, öğretmen ve öğrenci sayıları hayli düşüktür. 
DOǦU VE GÜNEYDOĞU ANADOLU BÖLGELERINDE EĞITIM VE.... 71

Tablo 3. Vilayetlere Göre Ortaokullar ve Bunların Öğretmen ve Öğrenci Miktarı

\begin{tabular}{|l|l|l|l|}
\hline Vilayetler & Okul Sayısı & Ŏğretmen Sayısı & Ö̆renci Sayısı \\
\hline Elazı̆̆ & 1 & 20 & 695 \\
\hline Erzincan & 1 & 14 & 385 \\
\hline Maraș & 2 & 20 & 336 \\
\hline Urfa & 1 & 19 & 317 \\
\hline Mardin & 1 & 13 & 265 \\
\hline Gaziantep & 1 & 21 & 237 \\
\hline Van & 1 & 10 & 174 \\
\hline Sïrt & 1 & 12 & 167 \\
\hline Bitlis & 1 & 7 & 134 \\
\hline Erzurum & 1 & 13 & 131 \\
\hline Ağrı & 1 & 8 & 85 \\
\hline Muș & 1 & 7 & 72 \\
\hline Toplam & 13 & 164 & 2.998 \\
\hline Toplam(Ulke & 125 & 2.509 & 37.905 \\
Geneli) & & & \\
\hline
\end{tabular}

Yukarıdaki vilayetlerde ortaokul sayısının Maraş haricinde sadece bir tane olması yanında bu okulların mevcut öğretmen sayılarının da öğrenci kapasitelerine göre düșük olduğu görülmektedir. Ayrıca Elazığ ve Gaziantep'teki öğretmen sayılarının yakın olmasına rağmen bu vilayetlerdeki ortaokulların ögrenci sayıları büyük fark arz etmektedir. Bu tür durumların eğitimde öğretmenin verimliliğini düşürdüğü bilinen bir sonuçtur. Tabloda birçok olumsuz göstergeye rağmen ortaokulların ülke genelindeki verileri de halen yaygun ve verimli bir eğitim seviyesine ulaşılamadığını da göstermektedir.

İlk ve ortaokullardaki sayısal durumun yanında, liselerdeki tablo incelendiğinde hem ülke genelinde hem de bölge vilayetlerinde, okullaşma seviyesinin ögretmen ve öğrenci sayısı yine istenilen düzeyde olmadı̆̆ görülmektedir. Özellikle öğrenci başına düşen öğretmen sayısının ülke ve bölge oranlamasında yaklaşık iki katlık bir fark ortaya çıkmaktadır. Sonuçta liselerdeki öğretmen açığının fazlalığı sonrasında, doğu vilayetlerinde her öğretmene 66 öğrenci düşerken, ülke genelinde bu rakam 38 öğrencidir.

Tablo 4. Vilayetlere Göre Liseler ve Bunlann Öğretmen ve Öğrenci Miktarı (1936-1937) ${ }^{15}$

\begin{tabular}{|l|l|l|l|}
\hline Vilayetler & Okul Sayısı & Ŏgretmen Sayısı & Ŏgrenci Sayısı \\
\hline Diyarbakır & 1 & 11 & 798 \\
\hline Erzurum & 1 & 13 & 691 \\
\hline Gaziantep & 2 & 11 & 659 \\
\hline Kars & 1 & 9 & 654 \\
\hline Malatya & 1 & 7 & 590 \\
\hline Toplam & 6 & 51 & 3.392 \\
\hline $\begin{array}{l}\text { Toplam(Ulke } \\
\text { Geneli) }\end{array}$ & 68 & 1.050 & 40.793 \\
\hline
\end{tabular}

${ }^{14}$ BCA: Fon Kodu: 030.01./90.559.2.

${ }^{15}$ BCA: Fon Kodu: 030.01./90.559.2. 
1937 y1lında ülke genelinde 68 lise bulunmakla birlikte doğu bölgesinde bu sayı altıda kalmıştır. Meslek liselerinin sayısı da yine ülke geneli ve bölge düzeyinde oldukça düşüktür. Liselerin birçok vilayet merkezlerinde dahi olmadığı dönem koşullarında, 1931 yılında mesleki ve teknik öğretim alanında Türkiye dokuz bölgeye ayrılmıștır. Diyarbakır bu merkezlerden biri olup burada masrafları bölgeye dâhil illerce karşılanmak üzere erkek öğrenciler için bir Bölge Sanat Okulu kurulmuştur. Ancak okulunun bulunduğu binanın mevcut ihtiyacı karşılayamadığından bu binaya yapılacak ilaveler için zaman zaman yeni ödenekler tahsis edilmiştir ${ }^{16}$.

Tablo 5. Vilayetlere Göre Meslek Okulları ve Bunların Öğretmen ve Öğrenci Miktanı (1936-

\begin{tabular}{|l|l|l|l|}
\hline Vilayetler & Okul Sayısı & Ŏğretmen Sayısı & Ŏğrenci Sayısı \\
\hline Diyarbakır & 1 & 13 & 105 \\
\hline $\begin{array}{l}\text { Toplam(UIke } \\
\text { Geneli) }\end{array}$ & 40 & 633 & 6.528 \\
\hline
\end{tabular}

Diyarbakır'daki sanat okulundan başka Doğu ve Güneydoğu Anadolu'nun bu tarihlerde tek öğretmen okulu Erzurum'da açılmıştır. Mevkiinin önemi sebebiyle Erzurum'da yaptırılması istenilen bu okul için, 02 Temmuz 1930 tarih ve 9682 numaralı kararnameye göre verilen inșaat müsaadesi; Maarif Vekâletinin 24.Temmuz 1930 tarih ve 5687 numaralı tezkeresiyle vuku bulan teklifi ve Maliye Vekâletinin 29 Temmuz 1930 tarihli mütaleanamesi üzerine İcra Vekilleri Heyetinin 29 Temmuz 1930 tarihli toplantısında tasvip ve kabul edilmiştir ${ }^{18}$.

Tablo 6. Vilayetlere Göre Öğretmen Okulları ve Bunların Öğretmen ve Öğrenci Miktarı

\begin{tabular}{|l|l|l|l|}
\hline Vilayetler & Okul Sayısı & Öğretmen Sayısı & Ŏğrenci Sayısı \\
\hline Erzurum & 1 & 12 & 113 \\
\hline $\begin{array}{l}\text { Toplam(UIke } \\
\text { Geneli) }\end{array}$ & 13 & 236 & 2.949 \\
\hline
\end{tabular}

Yukarıda aktarılan bilgilere ek olarak, 1923-1938 y1lları arasında ilkokul, ortaokul ve öğretmen okullarına ait kısıtlı imkânların çoğunlukla doğu vilayetlerine ait olduğu görülmektedir. Tahmin edileceği üzere bütün eğitim-öğretim kademelerindeki okullarda üst limitler Ankara, İstanbul, İzmir illerine aittir. Örneğin 1.000 'den fazla öğrencisi olan Ortaokul vilayetleri 1936-1937 ders senesinde sırasıyla: İstanbul, İzmir ve Ankara'dır.

\footnotetext{
${ }^{16} B C A$ : 11.1.1934, Fon Kodu: 030.10./173.198.7. ; BCA: 030.18.01.02/75.45.12

${ }^{17} B C A$ : Fon Kodu: 030.01./90.559.2.

${ }^{18} B C A: 29.07 .1930$, Fon Kodu: 030.10./13.53.19.

${ }^{19}$ BCA: Fon Kodu: 030.01./90.559.2.
} 
Bu göstergeler Cumhuriyet hükümetlerinin ilk on beş yilında ülke genelinde olduğu gibi doğu bölgesinde de istediği düzeyde eğitim yapılaşmasına gidemediğini gösterir. Ancak devletin yeni kurulmuş olması, asayişsizlik olaylarının henüz bitmesi, iktisadi durum ve birçok diğer etken bu gecikmeyi haklı kılmaktadır.

Tablo 7. tlkokul, Ortaokul ve Öğretmen Okullarının Vilayetlere Ait Bilgileri (1936-1937) ${ }^{20}$

\begin{tabular}{|l|l|l|l|}
\hline 2000'den Az Ilkokul Ŏgrencisi Olan Vilayetler \\
\hline Vilayetler & Ilkokul Sayısı & $\begin{array}{l}\text { Ŏğretmen } \\
\text { Sayısı }\end{array}$ & Oğrenci Sayısı \\
\hline Tunceli & 26 & 48 & 1.945 \\
\hline Ağrı & 17 & 37 & 1.343 \\
\hline Van & 12 & 36 & 1.201 \\
\hline Sïrt & 14 & 37 & 970 \\
\hline Bitlis & 11 & 26 & 875 \\
\hline Bingöl & 8 & 14 & 553 \\
\hline Mus & 6 & 17 & 539 \\
\hline Hakkâri & 3 & 6 & 155 \\
\hline 200'den Az Ortaokul Ŏgrencisi Olan Vilayetler & \\
\hline Kayseri & 2 & 28 & 177 \\
\hline Van & 1 & 10 & 174 \\
\hline Siirt & 1 & 12 & 167 \\
\hline Bitlis & 1 & 7 & 134 \\
\hline Erzurum & 1 & 13 & 131 \\
\hline Ağrı & 1 & 8 & 85 \\
\hline Muș & 1 & 7 & 72 \\
\hline 200'den Az Ŏgretmen Okulu Ŏğrencisi Olan Vilayetler \\
\hline Sivas & 1 & 14 & 151 \\
\hline Erzurum & 1 & 12 & 113 \\
\hline
\end{tabular}

Cumhuriyet'in ilanından sonra gerçekleștirilen eğitim seferberliğiyle okullaşma oranı artırılmaya çalışılırken hem doğu hem de ülkenin diğer vilayetlerinde bulundukları illerde okul açılmasını isteyen kişiler vardır ki bunların talepleri TBMM'de gündeme gelmeye başlamıştır. Örneğin 03 Aralık 1923 tarihinde Bitlis mebusu Resul Bey'in Rus istilasında yıkılan medreselerin yerine bir medrese inșası talebi 5 Aralık 1923'te Başvekil tarafından onaylanmıştır ${ }^{21}$.

Birinci Umumi Müfettişi İbrahim Tali Bey'in Ağustos 1932'de İsmet İnönü'ye Elazığ'da bir lise açılması hakkında yazdığı yazıda ise o yıllara ait ortaöğretim politikaları hakkında bilgi edinilebilmektedir. Raporda Tali Bey Elazığ da bir lise açılmasını şu cümlelerle talep etmiştir: "Diyarbakır ve

${ }^{20}$ BCA: Fon Kodu: 18.4.1939, 030.01./ 90.559.2.

${ }^{21}$ BCA: Fon Kodu: 30.10./6.33.14. Tevhid-i Tedrisat Kanunundan önce gerçekleșen bu başvuruda olduğu üzere Doğu ve Güneydoğu Anadolu bölgesinde medreselerde etkin bir vazife görüyordu. Tevhid-i Tedrisat Kanununun kabulü ile birlikte eğitim ögretimde ikilik kaldırılırken, 1928 Harf Inkılâbı ile birlikte büyük bir boşluk doğmuştur. Bu ise eğitimin bazen devletin denetimine alınmasını zorlaştırmıştır. 
Elazığ'daki Muallim Mekteplerinin kapatılması dört beş ay evvel taktim ettiği büyük raporun ruhuna pek muvafik olduğundan bu mekteplerin bir merkezde teksifi yolunda büyük faydalar temin edecek olan teșebbüsün başlangıcı olarak mucibi şükrandır, ancak Umumi Müfettişlik mıntıkasında zabıtan ve memurların en büyük endişeleri evlatlarının tahsilsiz birakılmaları olduğu gibi şark vilayetleri halkına yapılmakta olan birçok menfi propagandaların başında kendilerinin cahil birakılacağı suretinde hükümete karşı ağır ithamlarda bulunmaktadır. Birçok fena zanların karşılanmasına ve payansı faydaların teminine vesile olacağı aşikâr olan bir lisenin 1932 ders senesinde El'azizde ilk sinıfinın açılmasıını zaruri addetmekteyim. Muayyen nikbette yatıl talebe kulübüne müsait bina ve bir kısım eşyası da vardır. Bu mektebin açılmasına müsaade buyrulmasını arz ve istirhâm ederim." 22

Okul yapılmasına ve öğretmen ihtiyacına yönelik doğu bölgelerinden gelen bu tür talepler her zaman karşılanamamıștır. Maarif Vekâleti veya bizzat Başvekâlet bu isteklere olumsuz cevap verebilmişlerdir. Örneğin 15 Aralık 1936 tarihinde Üçüncü Umumi Müfettiş Tahsin Uzer'e Kültür (Millî Eğitim) ${ }^{23}$ Bakanı tarafından gönderilen yazıda maarifte öğretmen eksikliğinin paradan önce geldiği belirtilmiştir. Hocasız okul açmanın anlamsızlığına değinilen raporda son on yıldır öğretmen kadrosunun hemen hemen aynı kalmasına rağmen öğrenci sayısının yedi misli arttığı yazılmıştır. Cumhuriyetin ilk yıllarında ve daha sonraki yıllarda hatta günümüzde dâhi özellikle Doğu ve Güneydoğu Anadolu bölgesinin kasıtlı olarak eğitim politikalarında üvey evlat konumunda olduğunu iddia eden görüşlere raporda cevap verilmektedir. Rapor şu sözlerle devam etmektedir: “...Nitekim bu yll muallim kadrosuna daha bir tek kişi eklenmediği halde mevcut mekteplere mezunların yerlerini tutacaklardan bașka daha (yirmi beș bin) talebe başvuracaklardır. Ehliyetname alacak muallimlerin adedi henüz muayyen değildir. Ele geçecek hocaların mevcut mektep ilâve şubelerini idareye kifayet edeceği çok şüphelidir. Bu sıkışık durumda mektep açmamaktaki mücbir sebep sizce de teslim buyrulur. Muallim bulunduğu takdirde Karaköse; ilk açllacak mektepler listesine dâhildir. Fakat tekrar arz edeyim ki hoca bulunduğu takdirde. Sinır boylarında vatani vazifelerini yapan silah arkadaşlarımın bu çok kat'i ihtiyaçlarını temin edememek gibi elim bir vaziyette kalmanin beni ne kadar muzdarip ettiğinin en önce sizin hissedeceğinize kaniim. "24 Görüldüğü gibi dönemin kültür bakanının içten

${ }^{22}$ BCA: 4.8.1932, Fon Kodu: 030.10./69.457.7. Elazı̆̆'da olduğu gibi Malatya'da da lise açılması için Halk Partisi, Belediye, Ticaret ve Türk Ocağı Başkanlarının müşterek dilekçesi mevcuttur. Bkz, BCA: 28.6.1928, Fon Kodu: 30.10./143.28.3.

${ }^{23}$ Millî Eğitim Bakanlığı, Millî Mücadele Döneminde Maarif Vekilliği, 1923-27 Aralık 1935'e kadar Maarif Vekâleti, 28 Aralık 1935'den 21 Eylül 1941 yılına kadar Kültür Bakanlığı adını kullanmıștır.

${ }^{24}$ BCA: 15.7.1936, Fon Kodu: 30.10./142.20.7. 
ve samimi bu duyguları çok şey anlatmaktadır. Ancak eğitimin bu açık noktalarını maksatlı olarak ele alınması doğu bölgelerinin bir gerçeği olmuştur. Öyle ki yukarıda Birinci Umumi Müfettiş Tali Bey'in raporunda yer alan "...ş̧ark vilayetleri halkina yapılmakta olan birçok menfi propagandaların başında kendilerinin cahil bırakılacağı suretinde hükümete karşı ağır ithamlarda bulunmaktadır..." cümlesi devletin doğu vilayetlerine eğitim açısından da uzak durduğuna yönelik eleştirilere karşı uyanık olunması gerektiğini ispatlamaktadır.

Okulların açılma zamanı gelmeden kimsesiz ve fakir öğrencilere yer bulunabilmesi ve ihtiyaçlarının karşılanması için gerekenin yapılması amacıyla Dâhiliye Vekili tarafından Başvekile yazılan 08 Ekim 1932 tarihli belgede ise: "Mekteplerin açılma zamanı yaklaşır yaklaşmaz İstanbul, İzmir, Ankara gibi maarif müesseselerinin topluca bulunduğu yerlere diğer vilayetlerden bir talebe akın i başlamaktadır. Bunun, milletin tahsile olan şiddetli temayülünün ifadesi olarak şayan memnuniyet görüleceğine şüphe yoktur... Mekteplerde yer olmamasından ve yahut kabul şartların haiz olmamalarından dolayı arzularına muvaffak olamayan birçok çocuklar, mektep ve hükümet kapılarında çaresiz dolaşmağa başlıyorlar. Bunlardan bir kısmı, bin müşü̈latla ve mahalli yardımlarla memleketlerine dönebiliyorlar ve fakat oralarda meyus ve bedbin, hükümetin vatan çocuklarına bakmadığı ve yardım etmediği propagandasına alet oluyorlar..." 25 yazılmakta idi. Belgede ayrıca okuyamayan bu gençlerin han ve kahve köșelerinde kalarak işsizler hanesini çoğalttığı, şahsi hayat ve istikballeri ve memleket hesabına yararl 1 birer unsur olmalarının gerçekleşemediği vurgulanmaktadır. Bunun önüne geçebilmek için ise her sene nerelerde hangi okulların ne gibi şart ve niteliğe haiz olması gerektiğinin belirlenmesi ve ne kadar öğrenci alabileceklerinin tespit edilmesi istenmektedir. Yine bu okullara kabul şartlarının ne olduğu ve yerini temin etmeden gönderilecek çocukların neticeler karşısında nasıl sıkıntı ve tehlikelere maruz kalacaklarının, özellikle mektebi bitirmeğe namzet öğrencilere ve öğrenci velilerine idare amirleri, Maarif ve $\mathrm{CHF}$ teşkilatı tarafından iyice anlatılması, ilk muvafık tedbir olarak görülmüştür.

Bu yıllarda okul talepleri sadece Doğu ve Güneydoğu Anadolu bölgelerinden gelmemekteydi. Nitekim Üçüncü Umumi Müfettiş tarafından 01.05.1936 tarihinde İsmet İnönü’ye gönderilen bir raporda Karadeniz bölgesinin ortaokul ihtiyaçları belirtilmektedir. Karadeniz'in her kazasında ilkokuldan 40-80 çocuk çıktığı halde ancak yüzde biri veya ikisinin bir vilayet merkezine gidip orta tahsil yapabildiğini bildirilen raporda kaza halklarının okul binalarını yapmaya hazır olduklarına dikkat çekilmekte idi. Hatta Pazar kazasının bina parasını toplayarak Ziraat Bankasına yatırdığı,

\footnotetext{
${ }^{25}$ BCA: 08.10.1932, Fon Kodu: 030.10./142.20.1.
} 
Sürmene, Of, Akçaabat kazalarının da aynı güvenceyi verdiği ve ortaokul açılması için müsaade beklediği önemle belirtilmiştir. Rapordaki taleplerin özellikle İsmet İnönü'nün doğu illeri hakkındaki eğitim işlerine yönelik düşünceleri ve doğu halkının, burada Karadeniz bölgesi de bu yönde ele alınmıştır, ruhi gıdaları olan kültür ihtiyaçlarını arz etmelerinden kaynaklandığı da dikkat çekicidir ${ }^{26}$.

1923-1938 yıllarında bizzat Başvekâlete gönderilen yazılarda güç şartlarda ancak mevcut tüm imkânları kullanarak birer ilim yuvası olan okulların yapılmaya veya değişik uygulamalarla temin edilmeye çalışıldığı görülmektedir. Daha cumhuriyet ilan edilmeden önce İzmir, Konya ve Diyarbakır'da askeriye tarafindan el konulan binaların ${ }^{27}$ ve Gaziantep'teki eski postane binasının okul olarak kullanılmak üzere Maarif Vekâleti'ne devri isteği ${ }^{28}$, Gaziantep'te Emlak-1 Milliye'ye ait iki otel binasının Gaziantep Mektebi'ne tahsisi, ${ }^{29}$ Gaziantep'te Malatya Milletvekili Reșit Bey için ayrılan binalardan bir tanesinin okul olarak kullanıldığına ${ }^{30}$ dair bilgiler arşivlerimizden bize yansıyan birkaç örnektir. Ayrıca Bitlis'teki orta mektebin Muş’a nakli düşüncesi üzerine Bitlis ileri gelenlerinin 11 Ekim 1931 tarihli telgrafları ${ }^{31}$ bölge halkının eğitime olan ilgisini yansıtan diğer bir belgedir. Dördüncü Umumi Müfettişliğinden Dâhiliye Vekâletine gönderilen 30 Temmuz 1937 tarih ve 3001 sayılı raporda ${ }^{32}$ ise Tunceli vilayeti bölgesinde yapılan ve devam eden genel inşaata dair bilgiler verilmektedir. Buna göre Tunceli bölgesindeki asayişe yönelik tedbirlerden biri de eğitim kapsamında düşünülmüştür. On iki köy mektebinin inşası için gerekli emir ve talimatın verildiğini belirten bu rapor, aslında okul yapımında güvenlik kaygılarının da bir sonucunu göstermektedir.

Bölgeye ait raporlara göre, halkın aydınlatılması ve içtimai hayatın düzenlenmesi için idari tedbirler yanında okullara da gereken önem verilmelidir. Ancak bu okullar açılırken dikkat edilmesi gereken bazı hususlar olmalıdır. Buna göre; bölgenin genel yapısı, halkın ekonomik, sosyal ve kültürel durumları göz önüne alınarak iyi bir okul çeșidi seçilmelidir. Aksi halde hem memleketin kıt imkânları boşa harcanmıș hem

${ }^{26}$ BCA: 01.05.1936, Fon Kodu: 030.10./71.464.1.

${ }^{27}$ BCA: 22.07.1923, Fon Kodu: 030.10./143.27.4

${ }^{28}$ BCA: 12.11.1924, Fon Kodu: 030.18.1.1/11.55.14.

${ }^{29}$ BCA: 09.08.1925, Fon Kodu: 030.18.1.1/15.49.19.

${ }^{30} B C A: 22.11 .1926$, Fon Kodu: 030.10./143.27.21.

31 "Ankara büyük halaskar hazretlerine" denilerek gönderilen bu telgraf da altmış seneden beri vilayet merkezi olan ve kaza haline getirilen ve senelerdir muallim mekteplerini barındıran Bitlis'teki hastanenin ve orta mektebin kaldırılmaması talep edilmiştir. Bu telgrafin Başvekâlet müstesarı tarafından Maarif Vekâletine sorulması üzerine Maarif Vekili, Bitlis orta mektebinin Muş'a naklinin Muş halkı tarafından telgrafla talep edildiği ve kendilerine mektebin Muş'a naklinin mümkün olmadığı ancak bir sonraki ders yılında Muş'ta ayrica bir orta mektep açılmasının düșünüleceği cevabının verildiğini Başvekâlete bildirmiștir. $B C A$ : 11.11.1931, Fon Kodu: 030.10./178.226.7.

${ }^{32}$ BCA: 30.07 .1937 , Fon Kodu: 030.10./72.470.4. 
de eğitim-öğretim bakımından arzu edilen sonuçlara varılamamış olacaktır. Bu bakımdan bilhassa vilayet ve kaza yerlerinde leyli (yatılı) okullar açılmalıdır. Ayrıca buralarda ortaokul ve gece ilkokulları açılmalıdır. Arapça konuşan ve erkekleri Kürtçe bilen Siirt, Mardin, Midyat, Savur gibi yerlerde bilhassa kız okullarına önem verilerek, kızların okullara rağbet etmesi sağlanmalıdır. Hatta bu yapılırken birtakım teşvik edici hususlara da başvurulmalıdır. Bunlar arasında ikramiye, elbise, yemek vs. sayılabilir ${ }^{33}$.

\section{B. Bölgede Öğretmen Íhtiyact ve Eğitimde Bütçe Sorunu}

Bölgede eğitim ve öğretimi aksatan en önemli sorunlardan birisi ise okul sayılarına nispetle öğretmen eksikliğidir. Döneme ait raporlarda öğretmen istihdam politikası ve öğretmen tayinlerinde görülen eksiklikler de sık sık yer almaktadır. Raporlara göre, adetleri süratle artan okullarda öğretmen yetiştirmek meselesi, son on senenin en güç işlerinden biri görülmüş; bu meselenin halli, Maarif Vekâleti'nin muvaffakiyetlerinden birini teşkil etmiştir. Eğitimde başlıca mesele adet meselesi iken; artık kalite meselesine de daha fazla ehemmiyet verilmesi, bu sahada, ayrı ayrı mevzular için ayrı ayrı öğretmenler yetiştirilmesi meselesine çok dikkat edilmesi belirtilmiştir. Bazı esaslı noksanları görüldüğünden dolayı kapatılan köy öğretmen okullarının yerine başka bir vasıta bulunması istenmişti ${ }^{34}$.

Doğu vilayetlerimizde öğretmen yetersizliğinin geçmişe dayalı bir mesele olması ve bu konuda yapılması gerekenlerle ilgili kararlar da Talim ve Terbiye Kurulu ${ }^{35}$ 'nun etkisi de görülmektedir. Kurulun bu tür durumlarda konuyu kendi problemi olmaktan ziyade Öğretmen Okulları'nda çözülmesi gereken bir konu olarak görmesi dikkat çekmektedir. Millî Talim ve Terbiye Dairesi öğretmenlerin işini öğretmenlere bırakmak istemiștir. Öğretmenlerin yetiştirilmesi işiyle uğraşan Ögretmen Okulları (bugünün eğitim fakülteleri), öğretmen adaylarının doğu vilayetlerinde nasıl eğitim-öğretim faaliyetini uygulayacaklarını da planlayıp, anlatmak durumundadır. 1928 yılına ait bu konudaki örnek heyet kararı şöyledir:

${ }^{33}$ Pehlivanli, a.g.e., s.557-559.

${ }^{34}$ Ziya Gökalp Maarif meselesine dair yazdıklarında öğretmenlerin önemi ve onların sorunlarına şöyle değinmiştir:"Bir memlekette muallimler sınıfina içtimaî bir kıymet verilmezse ilim de haiz-i kıymet olamaz. Muallimlerin tesrifatta da mevkileri ve memurin-i mülkiyenin bazı derecelerine muadil mevkiiyle kaim rütbeleri olmalıdır. Muallimler maaş ve mevki itibariyle ne kadar yükselirse memlekette ilmin kıymeti de o kadar tezayüdeder. Bu mevkie kıymet verirken ona lâyık kimselerin mevcut olup olmadığı araştırılmalıdır. " Gökalp, a.g.e., s.120-121. Cemil Öztürk, Atatürk Devri Öğretmen Yetiştirme Politikast, Ankara, Türk Tarih Kurumu Basımevi, 1996, s.70, 71.

5 Talim ve Terbiye Kurulu, 2 Mart 1926 'da Tevhid-i Tedrisat kanunun uygulanması için kabul edilen Maarif Teşkilatı Hakkında Kanun ile birlikte kurulmuștur. Bu Kanun ile birlikte kurulan diğer bir kurum Maarif Eminlikleridir. Maarif Eminliği uygulamasına göre Türkiye 13 mıntıkaya ayrılmıştır: Ankara, Istanbul, Edirne, Izmir, Antalya, Konya, Adana, Gaziantep, Elazığ, Sivas, Van, Erzurum ve Trabzon. Gaziantep Bölgesi Maarif Eminliği 1928 yılında kaldırılarak Cebelibereket, Maraş ve Gaziantep illeri Adana bölgesine ilave edilmiştir. $B C A$ : 18.01.1928, Fon Kodu: 30.18.1.1/27.75.12. 
"Konya mintıkası Maarif Emaneti'nin 1431 numro ve 11.03 .1928 tarihli tahriratına melfuf olan Şark vilayetlerine gönderilecek genç muallimlerin oradaki vazifelerine taalluk eder bir talimatnamenin Vekâletçe tanzim edilmesine dair Konya Erkek Muallim Mektebi Müdürlüğü'nün müzekkiresi tetkik olundu.

Evvelâ: Bu sene Muallim Mektebleri mezunlarının Şark vilayetlerine gönderileceklerine dair heyetçe ittihaz olunmuş bir karar mevcut değildir. Mamafih Şark vilayetlerine gidecek ve oralarda çocukların talim ve terbiyesinden maada Türkleştirme vazifesini de ifa edecek olan gençlere ne suretle çalışacaklarını hedeflerine hangi yoldan ve ne suretle varacaklarını göstermek lazımdır. Fakat bunu mekteb müdürlerine birakmak lazımdır. Heyetimizce böyle bir rehber ve talimatnamenin hazırlanması ve bunun mekteblere tebliği muvâfik görülmemiştir. Alakadar mekteblere bu yolda tebliğatta bulunmasının temini için Orta Tedrisât Müdürlüğü'ne kararın bir sureti verilmesi karargîr oldu. "36

Talim ve Terbiye Kurulu'nun yukarıdaki örnek kararından başka Birinci Umumi Müfettiş Abidin Özmen'in hükümete hazırladığı raporda eğitimin meselelerine çözüm bulan yapıcı bir yaklaşım vardır. Özmen, bölgeye gelen memurların uzun süre görev yapmadıkları belirtilmiş, bu meselenin dürüst memurları Doğu'daki görevlerine gönüllü olarak bağlayacak şekilde çözülebileceğini yazmıştır. Raporda Kültür Bakanlığının bir kanunla bin öğrenciyi parasız okutma yetkisine sahip olduğu göz önünde bulundurularak bölgeye gelen memurların çocuklarının Kültür Bakanlığınca parasız okutulan çocukların onda birini teşkil etmesi tavsiye edilmiştir ${ }^{37}$.

MAH tarafından düzenlenen bazı bölge raporlarında ise ögretmen istihdam politikasındaki yanlışlıklara yer verilmiştir. Raporlara göre, bölgeye yapılan ögretmen tayinlerinde gerekli dikkat ve itina gösterilmemektedir. Bir raporda "idealsiz ve ülküsüz ögretmenler elindeki maarif çok geridir. Türk ögretmen hemen hemen yok gibidir" denilmektedir. Elazığ Valiliğinin 2 Ekim 1932 tarihli raporunda ise şu ifadeler yer almaktadır: "Yeni tayin edilen ögrretmenlerin bilgileri, eski ve yerli öğretmenlerin ise hem bilgileri, hem de görgüleri yeterli değildir. Bu yüzden buradaki yerli ve eski memurlar batıya tayin edilerek, yerlerine Türk kültür ve geleneklerini iyi bilen idealist ve ruh sahibi öğretmenler tayin edilmelidir. Bu bir zarurettir. "38

Aynı birimin öğretmen istihdamı sorunlarının çözümüne yönelik ilk tedbiri, bölgeden sıhhi ve çok önemli haller dışında çok sık ögrretmen tayini

${ }^{36}$ Güray Kırpık, “1926-1928 Yılları Arasında Talim ve Terbiye Kurulu'nun Aldığı Bazı Kararlar" Türkive Cumhuriyeti 'nin Kurulusunda Mimar Bir Kurum: Talim ve Terbive, Ankara 2008 (Baskıya Hazır Nüsha), s.101. Karar Tarihi: 16.03 .1928 (T.T.K. Karar Defteri, Cilt:4/1kinci Kısım, Karar Sayfası: 20, Karar No:14, Ankara, 1928)

S.Öztürk, a.g.e., s.84

${ }^{38}$ Pehlivanl, a.g.e., s.557-559. 
yapılmaması düşüncesi olmuştur. Zira hem bu tayinler mali külfet getirmekte, hem de öğretmenlerin bölgeyi ve bölge insanını, öğrencileri tanıma firsatları olmamaktadır. S1k sık gidip gelmelerden bölge eğitim ve öğretimi olumsuz etkilenmektedir. Diğer taraftan kız okullarına idealist hanım öğretmenler tayin edilmelidir. Bölgede Kürtçülük ve Arapçılık fikirlerinin yayılmasına göz yummamalıdır. Türk oldukları ve Türkçe bildikleri halde çeşitli sebeplerden dolayı Kürt olduklarını iddia eden bilhassa Dersim bölgesinde Türkçenin konuşulması yaygınlaştırılmalıdır ${ }^{39}$.

Öğretmen ihtiyacını karșılamak için hükümet tarafından yapılmak istenen en önemli politika şehir ve kasaba ilkokullarına öğretmen yetiştirilmesi ile birlikte köy öğretmeni yetiştirilmesi üzerine atılan adımlar olmuştur $^{40}$. 28 Şubat 1925 tarihinde TBMM'de Maarif Vekâletinin bütçe görüşmeleri yapılırken Maarif Vekili Şükrü Bey tarafından köy mektebi ve köy öğretmenlerinin gerekliliğine dair açıklamalar yapılmıştır. Böylece köy öğretmen okullarının ihtiyacı için öğretmenlerin köylerde tutunmaları ve artmalarını sağlayacak bazı tedbirler de alınmıştır. ${ }^{41}$ Ayrıca "Şark Vilâyetlerine Gidecek Muallimlere İtası Muktezi Maaş Zamları Hakkında Talimatnamenin Meriyede Vaz'ına Dair Kararname" 42 ile Artvin, Ardahan, Erzurum, Ergani, Ağrı, Bitlis, Hakkâri, Siirt, Süleymaniye, Kars, Kerkük, Genç, Muş, Musul, Van, Dersim ve Erzincan vilâyetlerindeki ortaöğretim okullarına gönderilen öğretmenlere maaş ve fevkalâde tahsilât öngörülmüştür. 4 Mayıs 1927'de "Uzak Vilâyetlerde İstihdam Olunan Maarif Memurlariyla Muallimlere Verilmesi Lazım Gelen Zamaim Hakkındaki Talimatnamenin Mevkii Meriyete Vaz' ' Hakkında Kararname e,43 ile illere göre farklı zam oranları verilmiştir. Doğu vilayetlerinde çalışan öğretmenlerin maaşını gösteren cetveller ${ }^{44}$ incelendiğinde bölge öğretmenlerine teşvik mahiyetinde verilen bu fevkalade tahsisat ve uzaklık zamları net olarak görülmektedir. Böylece bu tür uygulamalarla bölgedeki

${ }_{40}^{39}$ A.g.e. çalışmalarına başlanmış, yine 1930'lu yillarda diğer önemli bir okul ordu olmuştur. Bölge gençleri askerlik hizmeti için öncelikle batı bölgelerine gönderildi. Batı Anadolu'ya gönderilen bölge çocuğu askerlere Türkçe öğretilecek iyi birer vatandaş olmalarına çalışıldı. Bunlara askerlik dönüşü muhtarlık görevi verildi ki, bu bir bakıma ödüllendirmeydi. Hüseyin Koca: Yakın Tarihimizden Günümüze Hükümetlerin Doğu ve Güneydoğu Anadolu Politikaları, Konya 1998, s.351.

${ }^{41}$ Cumhurbaşkanları, Başbakanlar ve Millî Eğitim Bakanlarının Millî Eğitimle Ilgili Söylev ve Demeçleri, Ankara, Türk Devrim Tarihi Enstitüsü, 1946, s.291 ;Öztürk, a.g.e., s.64 Söylev.
vd.

42 Düstur, D. 2, c. 6, 7 Haziran 1925, No: 2049, s.709, 710 ;BCA: 07.06.1925, Fon Kodu: $30.18 .1 .1 / 14.36 .1$.

${ }_{44}$ Dïstur, D. 2 , c. 8,4 Mayıs 1927 , No: 5113 , s.512-514.

441930 yılındaki Mardin ve Urfa vilayetlerinde çalışan öğretmenlerin maaşını gösteren cetvellerde asıl maaş miktarından fazla fevkalade tahsisat ve uzaklık zammının verildiği görülmektedir. Bkz, BCA: 8.3.1930, Fon Kodu: 030.10./134.962.13. ;BCA: Fon Kodu: 030.10./134.962.9. 
öğretmen eksikliği giderilmek istenmiştir. Gerçekten ülkenin eğitimi için elden gelen birçok çare aranmış ve bu devletin maarif işlerine verdiği önem doğrultusunda tüm ülkeye yansıtılmaya çalıșılmıștır. Yıllara göre maarif bütçelerine bakıldığında hükümetlerin Millî Eğitim masraflarına önemli miktarda kaynak artırdığı ve bu bütçelerin genellikle yıllara göre artış kaydettiği görülmektedir. Millî Eğitime verilen bu önemden dolayı Cumhuriyetin ilk yıllarında Türkiye Cumhuriyeti'nin kalkınması büyük ölçüde eğitim yolu ile olmuştur.

\begin{tabular}{|c|c|c|c|}
\hline Yillar & Maarif Bütcesi-TL & Yillar & Maarif Bütçesi-TL \\
\hline 1923 & 3.033 .003 & 1931 & 7.967 .092 \\
\hline 1924 & 6.178 .505 & 1932 & 7.195 .324 \\
\hline 1925 & 7.517 .999 & 1933 & 10.360 .103 \\
\hline 1926 & 7.054 .056 & 1934 & 9.681 .316 \\
\hline 1927 & 7.541 .727 & 1935 & 10.693 .328 \\
\hline 1928 & 9.631 .033 & 1936 & 11.260 .905 \\
\hline 1929 & 9.323 .432 & 1937 & 13.714 .371 \\
\hline 1930 & 9.710 .297 & 1938 & 16.474 .085 \\
\hline
\end{tabular}

Tablo 8'de görüldüğü gibi cumhuriyetin kuruluşundan itibaren maarif bütçesinde, dünya ekonomik buhranı sonrası 1931 ve 1932 yılarında yaşanan düşüşe rağmen, bir artıș gözlenmektedir. Fakat yeni kurulan ve kalkınmasını eğitimle yapacak bir devlet için bu bütçe rakamlarının her zaman doyurucu olmadığı da açıktır. Devraldığı eğitim kurumları ve eğitim sistemi açısından işe hemen hemen sıfurdan başlayan devlet, eğitimde yeni yeni sorunlarla karșılaşmıștır. Nitekim Anadolu'nun birçok yerinde olduğu gibi Doğu ve Güneydoğu Anadolu vilayetlerinde de maarif için vilayet gelirlerinden ayrılan pay ihtiyacın yarısını bile karșılayamamıștır ${ }^{46}$. Bu durum Diyarbakır, Erzincan, Urfa, Malatya, Mardin, Siirt, Van, Ağr ${ }^{47}$ gibi vilayetlerin İl Özel İdare Bütçesi maarif tahsisatının artırılmasına yönelik taleplerine neden olmuştur. Ayrıca Erzurum, Ağrı, Urfa, Maraş ve Mardin ${ }^{48}$ vilayetleri İl Özel

${ }^{45} B C A$ : Fon Kodu: 30.01./90.559.4. ;TBMM'deki Maarif Vekâleti bütçe görüşmeleri için bkz. Cumhurbaşkanları, Başbakanlar ve Millî Eğitim Bakanlarının Millî Eğitimle Ilgili Söylev ve Demeçleri, Ankara, Türk Devrim Tarihi Enstitüsü, 1946.

${ }^{46}$ Pehlivanl, a.g.e., s.557-559.

${ }^{47} B C A:$ 24.10.1927, Fon Kodu: 30.18.1.1/26.58.10. ;BCA: 15.06 .1928 , Fon Kodu: 30.18.1.1/29.37.13.; BCA: 05.04.1934, Fon Kodu: 030.10./174.200.7. ;BCA: 13.10.1927, Fon Kodu: 030.18.1.1/26.56.20; $B C A$ : 24.10.1927, Fon Kodu: 030.18.1.1/26.58.2. ;BCA: 10.06.1928, Fon Kodu: 030.18.1.1/29.36.20; $B C A$ : 16.05.1928, Fon Kodu: 030.18.1.1/29.31.4 ; BCA: 04.12.1927, Fon Kodu: 030.18.1.1/26.66.17.; BCA: 12.07.1928, Fon Kodu: 030.18.1.1/29.42.13 ; $B C A$ : 04.12.1927, Fon Kodu: 030.18.1.1/26.66.17.; BCA: 12.07.1928, Fon Kodu: 030.18.1.1/29.42.13 ;BCA: 28.05.1928, Fon Kodu: $030.18 .1 .1 / 29.35 .6$

BCA: 18.01.1928, Fon Kodu: 030.18.1.1/27.75.4. :BCA: 11.01.1928, Fon Kodu: 030.18.1.1/27.74.7.;BCA: 30.01.1928, Fon Kodu: 030.18.1.1/27.77.6. ;BCA: 030.01.1928, 
İdaresi maarif ödeneklerinin yetersizliği sebebiyle çözümü sayım, kazanç, arazi ve müsakkafat vergilerinin artırılmasına yönelik kararlar alarak bulmaya çalışmıştır.

Doğu bölgelerinin mevcut eğitim sorunlarına bu vilayetlerde çalışan öğretmenlerin zaman zaman maaşlarını alamamaları eklenmiştir. Maarif Vekilleri bu tür meselelere özel önem vermişlerdir. İlk TBMM döneminde Maarif Vekili olan Rıza Nur'dan itibaren öğretmenlerin aylık alamamaları ile ilgili sorular Mecliste görüşülen konulardan biri olmuştur. ${ }^{49} \mathrm{Bu}$ konu cumhuriyetin ilanından hemen sonra 12 Kasım 1923 tarihinde yine Meclis gündemine taşınmıștır. Dönemin Maarif Vekili olan İsmail Safa Bey burada yaptığı konuşmasında mevcut sıkıntılı dönemden sonra idarei hususiyelerin aşar taksitlerini toplamaya başlaması ile birlikte öğretmenlerin maaşlarının ödenmeye başladığını açıklamıştır. İsmail Safa Bey’den sonra Maarif Vekili olan Şükrü Bey de 27Aralık 1924 tarihinde ilkokul öğretmelerinin aylıkları hakkındaki kanun tasarısında eğitimin bu yönüne yeniden değinmiştir. ${ }^{50} \mathrm{Bu}$ bakanlardan biri olan Esat Sagay Bey beraberinde Mülkiye ve Maarif Müfettişleriyle Niğde'ye gitmiştir. Niğde vilayeti ilkokul öğretmenleri maaşları hakkında yapılan araştırmanın yanı sıra ${ }^{51}$ Silifke, Gaziantep, Kilis, Cebelibereket (Osmaniye) gibi bazı vilayet ve kazalardaki öğretmenlerin maaşları ödenemediği için bu vilayet bütçelerini de tetkik ettirilmiştir ${ }^{52}$. Bunun üzerine Niğde'ye ait iki, Cebelibereket, İçel ve Gaziantep vilayetlerine ait birer olmak üzere toplam beş rapor Maarif Vekiline sunulmuştur. 07 Eylül 1932 'de Mülkiye ve Maarif Müfettişlerinin ortak olarak Gaziantep vilayetinin maaş durumu hakkında hazırladıkları rapor ${ }^{53}$, bu vilayetin maaş sıkıntısını tespit eden sebepleri ve öğretmenlerin maaş vaziyetini tetkik ederek Maarif Vekiline arz edilmiştir. Maarif Bakanı ise, 8 Eylül 1932 tarihinde, Başbakan İsmet Paşa'ya gönderdiği yazıda gerek Niğde, gerekse Cebelibereket, Gaziantep ve İçel vilayetlerine ait öğretmen maaşlarının ödenmesindeki sıkıntılara yönelik bir rapor sunmuştur. Başbakana gönderilen bu belgede ve Gaziantep ile ilgili olarak Esat Bey’e

Fon Kodu: 030.18.1.1/27.77.6. ;BCA: 20.09.1927, Fon Kodu: 030.18.1.1/25.52.4. ;BCA . 20.09.1927, Fon Kodu: 030.18.1.1/25.52.1.

${ }_{49}$ Cumhurbaşkanları, Başbakanlar ve Millî Eğitim Bakanlarının Millî Eğitimle İlgili Söylev ve Demeçleri, Ankara, Türk Devrim Tarihi Enstitüsü, 1946, s.158-164.

${ }_{50}$ A.g.e., s.254-255, $285 \mathrm{vd}$.

${ }^{51}$ BCA: 08.09.1932, Fon Kodu: 030.10./142.17.2.

${ }_{53}$ BCA: 04.09.1932, Fon Kodu: 030.10./142.16.21. gayesiyle iki senelik vilayet bütçelerinin tetkik edildiği bu raporda, Gaziantep vilayetinin 1930, 1931 yılı bütçeleri, kadrolarda tasarruf durumu, tali masraflar, eski yıllardan kalan borçlar, tahsilâtın şekli ve vaziyeti, vilayetin matlubatı, öğretmenlerin maaş vaziyeti ve vilayetin mali sıkıntısını tevlit eden sebeplerin neler olduğuna dair bilgiler yer almaktadır. Aynı belgeye göre öğretmenler Gaziantep vilayeti merkezinde temmuz, ağustos, Kilis'te haziran, temmuz, ağustos, Nizip ve Besni'de ağustos masşlarının verilemediği ve tedahülde kalan bu maaşların tediyesi için 18300 liraya ihtiyaç olduğu belirtilmiştir. $B C A$ : 07.09.1932, Fon Kodu: 030.10./142.17.1. 
gönderilen rapor doğrultusunda maaş tediyesindeki sıkıntının sebeplerin genel nedenleri ve özel olarak Gaziantep örneği şu şekildedir:

"1-Varidat ile tahakkuk ve tahsil arasında bariz farklar vardır. Bu yüzden bidayette maşlara tercihan yapılan masraflar dolayısıyla maaş tediyesine imkân bulunamamıștır.

2-1930-1931 mali senelerinde bazı mintıkalarda varidat tahsilinde azami faaliyet gösterilememiş, varidatın tahakkukuna nazaran tahsilâtın temini için kanuni haciz ve tevkif tedbirlere kâfi nispette müracaat edilmemiştir.

3-Birkaç sene tehiri mümkün görülen inşaat tercihen yapılmıştır. (Niğde, Gaziantep).

4-Yol mükellefiyeti gibi varidatın çoğalmasına yardım edecek mükellefiyetler mümkün olabilecek haddinden noksan bırakılmıştır. (Niğde, Gaziantep).

5-Teberru ve muavenet gibi masraflar tercihan yapılmıştır. (Niğde, Gaziantep).

6-Eski senelerden müdevver düyun zaruri olarak tediye edilmiştir.

7-Birkaç seneden beri hususi muhasebe esaslı bir teftişe tabi tutulmamıştır.

8-Hususi idarenin maliyeden aldığı emlak taksitleri ödenemediğinden başka yerlere sarfiyat yapılamaması (Gaziantep, Kilis).

9-Tedavülde bulunan gümüș para ile nakdi evrak arasındaki fark hesabı ile tahsilâtın azalması (Gaziantep).

10-Gaziantep vilayetinin kuraklıktan (1932) müteessir olması.

11-Tahsilâtta haciz ve tevkif gibi tedbirlere kâfi nispette müracaat edilememesi (Gaziantep).

12-Bütçe açığı olmasına rağmen her yıl bütçesine merbut kadroların arttırılmas1 (Gaziantep)." ${ }^{54}$

Cumhuriyet döneminin eğitimdeki maaş sıkıntısının sadece Doğu vilayetlerine ait olmadığının bir örneği Abidin Özmen'in raporundan anlaşılmaktadır. Yıllarca ilkokul öğretmenlerinin maaşlarının ödenememesi üzerine Ordu'da radikal bir karar alınmıştır. Vilayette kırktan fazla öğretmen

${ }^{54}$ BCA: 08.09.1932, Fon Kodu: 030.10./142.17.2. ; BCA: 07.09.1932, Fon Kodu: 030.10./142.17.1. 
çıkarılmış, karmaşık okullarda kapanmıştır. Öğretmenlerin birikmiş maaşları yirmi sekiz bin liradır. ${ }^{55}$

Esat Sagay'dan sonra Maarif vekili olan Reșit Galip Bey'in görevinin ilk günlerinde İstanbul'da Anadolu Ajansına yaptığı șu konușma konuya bir örnektir: "Eylül nihayetine kadar mütedahil muallim maaşlarının kâmilen tesviyesi işini ehemmiyetle takip ediyorum. Bundan sonra kendileri aldıklar halde muallimleri aylıksız biraktıkları görülecek hususi muhasebelerin yakalarından tutacağım." "56 30 Mayıs 1934 tarihinde Millî Eğitim Bakanı Yusuf Hikmet Bayur'un Başvekâlet makamına gönderdiği yazı ise yine öğretmenlerin aksayan maaşlarıyla ilgilidir. Buna göre Kars Kağızman öğretmenlerinin maaşların aksamasına yönelik telgrafları üzerine Maarif Vekâleti Kars vilayetine durumu sormuștur. Kars Maarif Müdürlügünden alınan 13 Mayıs 1934 tarihli ve 94 numaralı telgrafa göre merkez ögretmenlerinin Şubat, Mart, Nisan, Sarıkamış, Arpaçay, Ardahan, Posof, Çıldır öğretmenlerinin Mart, Nisan ve Mayıs, Kağızman Göle ögretmenlerinin de Nisan ve Mayıs ayı maaşlarını alamadıkları bildirilmiştir. Bunun üzerine Dâhiliye Vekili ile yapılan toplantı sonunda Kars vilayetinin mali vaziyetinde görülen sarsıntının sebepleri ile vilayetin hatalı muameleleri hakkında tetkikte bulunmak için bir bakanlık müfettişinin gönderilmesi kararlaştırılmıştır ${ }^{57}$.

Millî Eğitim Bakanı Yusuf Hükmet Bayur'un tarihi tetebbularla meşgul olmak üzere istifa etmesi üzerine onun yerine Aydın Mebusu Abidin Özmen bu görevi devralmıştır. Onun 09 Haziran 1935 tarihinde Birinci Umumi Müfettişliğe tayin edilmesi sonrası ise yeni bakan Köy Enstitülerinin bir kısmının kurulmasında vazife alacak olan Saffet Arıkan'dır ${ }^{58}$. Saffet Arıkan köy öğretmeni yetiştirme programını bazı doğu vilayetlerinde de uygulayarak bu bölgedeki eğitici eksikliğini gidermeyi düşünmüștür. $\mathrm{Bu}$ amaçla deneme niteliğindeki Çifteler Eğitim Kursu'ndan başarılı sonuçlar alınması üzerine Millî Eğitim Bakanlığı, 1937-1938 eğitim-öğretim yılında eğitmen kurslarının sayısını artırmaya karar vermiştir. Nitekim bu öğretim yılı için, Kültür Bakanlığı'nın ilgili memurları Ankara'nın Çubuk, Ayaş, Polatlı, Afyon'un Aziziye, Erzincan'ın Kelkit, Tercan, Pasinler kazalarında, Eskişehir, Kars, Edirne ve Kırıkkale civarında eğitmen kursları için öğrenci seçmeye başlamıştır. Bu okulların, 18 Nisan 1937'de Eskişehir, Kars, Edirne, Erzincan ve Kocaeli'nde açılması kararlaştırılmıştır. Arıkan'ın

\footnotetext{
${ }^{55}$ S. Öztürk, a.g.e., s.52-53.

${ }_{57}^{56}$ Hâkimiyet-i Milliye. 25 Eylül 1932.

${ }_{58}^{57}$ BCA: 30.5.1934, Fon Kodu: 030.10./142.17.8.

Mustafa Yazıcı, Tanzimat'tan Bu Yana Millî Eğitim Bakanlar Basbakanlar ve Atatürk (1839-1973). Ankara, Emel Matbaacılık, 1973, s.126-127. Üç dört yıl içinde 21 köy enstitüsü kurulurken doğu vilayetlerinde de 5 enstitü açılmıştır. Bunlar: Malatya-Akçadağ, Kars-Cilavaz, Erzurum-Pulur, Diyarbakır-Ergani/Dicle, Van-Erciş Köy Enstitüleridir. Cumhuriyetin 50. Yılında Millî Eğitimimiz, İstanbul 1973, s.147.
} 
Temmuz 1938'de doğuya yaptığı gezi bu açıdan yararlı olmuştur. Van, Tatvan, Ahlat, Adilcevaz gibi yerlerde Umumi Müfettiş Abidin Özmen ile tahkikat yapan Arıkan Erciş ve oradan Kars'a geçmiștir. Kars'ta refakatinde umum müdürleri ve vilayetin kültür direktörü olduğu halde kılavuz eğitmen kursunu teftiş etmiş ve ildeki eğitim ile ilgili diğer yerleri tetkik etmiştir ${ }^{59}$. 17 Temmuz 1938'de Erzincan'da gezisine devam eden Millî Eğitim Bakanı daha sonra Trabzon'a geçmiştir. Bakanın doğu gezisi ile ilgili olarak 19 Temmuz Ulus-Ankara'da şu haber yer almıştır:

“...Diğer taraftan, Maarif Vekilimizin șark seyahati hakkında aldiğımız haberler de bizi çok sevindirecek mahiyettedir. Şark vilayetinde bir kültür sitesi kurulması hakkında Atatürk'ün verdikleri direktife göre tetkiklerde bulunmak üzere bu seyahate çıkan Maarif Vekilimiz koca bir bölgede bir gün bir kültür ocağının temelini atarak, bir başka gün maarifçilerle hasbıhal ederek en çok nura muhtaç olan o yerlerin ihtiyaçlarını yakından tespit ve alınması zaruri tedbirlerin mahiyetini tayin etmek imkânını bulmuştur. ${ }^{\circ 60}$

Millî eğitim sistemi içinde öğretmen istihdamı ve onların maaşlarıyla ilgili olan eğitim bütçesine yönelik sorunlar okul binalarının ve oraların araçgereçlerinin temini noktasında da kendini göstermiștir. Nitekim cumhuriyetin ilanından sonra sanat okullarının giderlerini karşılaması amacıyla bakanlık yeni bir yol bularak sanat okullarına Bölge Sanat Okulu adı vererek birkaç ili sorumlu tutmuştur. Böylece bu illerden para sağlanmak istenmiștir. Ancak iller içlerinde bulunmayan okullara yardım konusunda mali olarak yetersiz kalmıș veya bu konuda isteksiz davranmıștır. Ankara veya Aydın'daki sanat okuluna bir başka vilayet neden para ödeyecektir? Bu durum illerin sanat okulu borçlarını biriktirmiş ve çıkarılan bir kanunla bu borçlar affedilmek zorunda kalınmıștır. 1935'e gelindiğinde ise Maarif Bakanlığı kesin cözüm olarak sanat okullarının idaresini ve giderlerini kendi üzerine almıștır ${ }^{61}$. Fakat bu zamana kadar geçen sürede doğu vilayetlerinin de bu mıntıka uygulamasından oldukça olumsuz etkilendikleri görülmüștür. Örneğin Diyarbakır valiliğinden Bașvekâlete gönderilen ve Diyarbakır Sanat Mektebi için yardım yapılması istenilen yazıda, Diyarbakır sanat mektebi için vilayetlerin taahhüdünün 45.000 lira olduğu belirtildikten sonra, 1933 senesinden Urfa vilayetinin 13.384, Van vilayetinin 845, Erzurum vilayetinin 7.127 lira 15 kurus borçlarının kaldığı açıklanmıștır. Erzurum vilayetinin 1932 senesinden kalan borcuda 13.156 liradır $^{62}$. Nitekim bu konu ile ilgili olarak Diyarbakır ve Ankara Sanat Okulu iștirak hisselerine Van Valiliği'nin tahsisatını gösteren yazıda: Diyarbakır ve Ankara Sanat Okulları

\footnotetext{
${ }^{59}$ Ayın Tarihi, Sayı: 56, Ağustos 1938, s.3-5 ; Öztürk, a.g.e., s.177-178.

${ }^{60}$ Aym Tarihi, Say1: 56, Ağustos 1938, s.47.

${ }^{61}$ Ilhan Başgöz, Türkiye'nin Eğitim Çıkmazı ve Atatürk, Ankara, Başbakanlık Basımevi, 1995, s.211-212.

'62 BCA: 11.01.1934, Fon Kodu: 030.10./173.198.7.
} 
hissesinden 1933 senesine mahsuben Diyarbakır vilayetine, 07 Eylül 1933 tarihinde 1.000 ve Ankara vilayetine 04 Ocak 1934 tarihinde 1.000 ve yine Ankara vilayetine 17 Mart 1934 tarihinde 1.000 lira ki toplam 3.000 lira tediyat yapılmış ve 1932 senesinden 332 lira ve 1933 senesinden 1.834 lira ki toplam 2.166 lira borcun kaldığı ve bu borcun iki ay içinde tamamıyla ödeneceği bildirilmiştir ${ }^{63}$.

Gaziantep vilayet bütçesine sanat okulları için konulan ödenek hakkında Başvekâlete gönderilen telgrafta ise, Aydın Sanat Mektebi için 1932 ve 1933 senelerine ait tahsisatın miktarı, o zamana kadar gerçekleştirilen ve borç olarak kalan miktarın ne olduğu açıklanmaktadır. Bu iki yıla ait tahsisatta dikkati çeken temel durum Antep vilayetinin diğer vilayetlerde olduğu gibi mali darlık sebebiyle sanat mektebi için gerekli ödemeyi zamanında yapamadığıdır ${ }^{64}$. Nitekim Maraş Valiliğinden Başvekâlete gönderilen 10 Mart 1934 tarihli yazıda ise bu ilin bütçe azlığından dolayı mıntıka sanat mektebine olan (Aydın) 15.189 liralık borcun ödenemeyeceğ $i^{65}$ ve Niğde ve Malatya valiliklerinin de 03 Nisan 1934 tarihli yazıda Konya Sanat Okuluna yapmaları gereken tahsisatı yapamadıkları açıkça bildirilmiștir ${ }^{66}$.

Tablo 9. Gaziantep Vilayeti İdare-i Hususiyesine Ait Aydın Sanat Mektebinin İştirak Hissesini Gösteren Cetvel (1934)

\begin{tabular}{|l|l|l|l|l|l|l|}
\hline \multirow{2}{*}{$\begin{array}{l}\text { Mali } \\
\text { Seneler }\end{array}$} & $\begin{array}{l}\text { Iștirak } \\
\text { Toplamı }\end{array}$ & \multicolumn{1}{|c|}{ Hissesinin } & \multicolumn{4}{|l|}{ Iștirak Hissesinin } \\
\cline { 2 - 7 } & & & $\begin{array}{l}\text { Tediye } \\
\text { Miktarı }\end{array}$ & Edilebilen & $\begin{array}{l}\text { Henüz } \\
\text { Olunmayan }\end{array}$ \\
\hline & Lira & Kuruș & Lira & Kuruș & Lira & Kuruș \\
\hline 1931 & 8173 & & 6702 & 44 & 1470 & 56 \\
\hline 1932 & 12258 & & 3500 & & 8758 & \\
\hline 1933 & 9700 & & 4100 & & 5600 & \\
\hline Toplam & 30131 & & 14302 & 44 & 15828 & 56 \\
\hline
\end{tabular}

\section{SONUÇ}

Cumhuriyet'in ilanından sonra Türk toplumunu çağdaş medeniyet seviyesine ulaştırmak, ülkenin ilerlemesini önündeki engelleri kaldırmak, laik ve millî bir toplum oluşturmak için Atatürk inkılâplarının uygulanmaya başladığı görülmüştür. Ancak Türk inkılâbının başarısının eğitim alanındaki başarıya bağlı olduğu gerçeği, eğitimin yaygınlaşması ve değişmesi için

${ }^{63}$ BCA: 25.03.1934, Fon Kodu: 030.10./173.199.12.

${ }_{65}^{64} B C A: 04.01 .1934$, Fon Kodu: 030.10./173.197.10.

${ }^{65}$ BCA: 15.03 .1934 , Fon Kodu: 030.10./173.199.3.

${ }_{67}^{66} B C A: 03.04 .1934$, Fon Kodu: $30.10 . / 174.200 .2$.

${ }^{67} B C A$ : 09.04.1934, Fon Kodu: 030.10./176.200.11. Gaziantep vilayetinin 15828 lira 56 kuruşluk borcundan Malatya'ya bağlanan Besni'ye ait 2728 lira 56 kuruşluk kısmın düşmesiyle tediye olunmayan miktar 13100 lira olmuştur. 
kararlı ve acil adımların atılmasını zorunlu kılmıştır. Bu amaçla Atatürk döneminde eğitim ve öğretimin her alanında köklü çözümlere gidilmiştir.

1923-1938 yılları arasında Türkiye'de gerçekleștirilen eğitim seferberliğinin Doğu ve Güneydoğu Bölgesi'ndeki vilayetlerde de olabildiğince gerçekleştirilmeye çalışıldığı yukarıdaki konular kapsamında görülebilmektedir. On beş yıllık bu dönemde ilkokul düzeyinde yoğun olarak görülen eğitim faaliyetleri zamanla orta ve lise seviyesinde de tatbik edilmeye çalıșılmıștır. Doğu bölgesinin okullaşma bakımından özellikle ilkokul sonrası eğitim çalıșmalarında yetersiz bir tablo göstermesine rağmen buralardaki öğretmen ve okul sayısının ülkenin diğer bölgelerinden tamamen kopuk ve geri olduğunu söylemek mümkün değildir. Nitekim ülkede genel bir okullaşma ve öğretmen yetiștirme hamlesi vardır ve bu tür sorunları her vilayet az veya çok yaşamaktadır.

Fakat bugün olduğu gibi 1923-1938 yılları arasında da Doğu ve Güneydoğu Anadolu Bölgesi'nin eğitim durumundaki yetersizlikte, bölgede ulaşımın güçlüğü, yerleşim birimlerinin dağınık olması ve halkın önemli bir kısmının kırsal kesimde yerleşik veya göçer olarak yaşıyor olması, ailenin vermiş olduğu geleneksel eğitimin varlığı, eğitim çağındaki nüfusun çalışması ve halkın geçim kaynağının tarım ve hayvancılık olması nedeniyle eğitime olan gereksinimin azlığı, devlet tarafından götürülen eğitim hizmetlerinin yetersizliği, özellikle ilköğretim sonrası eğitimin zaman ve masraf gerektirir olması, gibi faktörler etkili olmuştur. Bu amaçla 1923 yılından itibaren bölgedeki yerel yönetim ve eğitim kurumları, idari bakımdan oluşturulan bölge müfettişliği uygulaması ve bölgenin güvenlik meseleleri çerçevesinde eğitim faaliyetlerini de irdeleyen özel çalışma masaları doğu vilayetlerinin eğitim meselelerine özel olarak eğilmişlerdir. Böylece bu birimlerin kaleme almış olduğu raporlar ve merkez ile olan yazışmaları bölgesel faklılığın getirdiği sorunları çözmeye yönelik olmuştur.

\section{KAYNAKÇA}

\section{A.Resmi Yayınlar}

Ayın Tarihi, Sayı: 56, Ağustos 1938

Başbakanlık Cumhuriyet Arşivi Katalogları(BCA)

DİE, Ístatistik Ylllığı, c.2, Y.l: 1929

DİE, İstatistik Yıllığı, c.5, Yıl: 1931-1932

Diistur, D.2, c.6, 7 Haziran 1925, No: 204

Dïstur, D.2, c.8, 4 Mayıs 1927, No: 5113

Hâkimiyet-i Millîye, 25 Eylül 1932 


\section{B.Kitaplar}

AKYÜZ, Yahya, Türk Eğitim Tarihi, Ankara, Pegem Yayıncılık, 2006

BAŞGÖZ, İlhan, Türkiye'nin Eğitim Çıkmazı ve Atatürk, Ankara, Başbakanlık Basımevi, 1995

Cumhurbaşkanları, Başbakanlar ve Millî Eğitim Bakanlarının Millî Eğitimle İlgili Söylev ve Demeçleri, Ankara, Türk Devrim Tarihi Enstitüsü, 1946

Cumhuriyetin 50.Yılında Millî Eğitimimiz, İstanbul, 1973

GÖKALP, Ziya, Milli Terbiye ve Maarif Meselesi, Ankara, 1972

, Terbiyenin Sosyal ve Kültürel Temelleri, İstanbul, Millî Eğitim Basımevi, 1973

KARAL, Enver Ziya, Atatürk'ten Düşünceler, Ankara, ODTÜ Gelişme Vakfi Yayıncılık ve İletișim, 1998, s.62

KIRPIK, Güray, “1926-1928 Yılları Arasında Talim ve Terbiye Kurulu'nun Aldığı Bazı Kararlar" Türkiye Cumhuriyeti'nin Kuruluşunda Mimar Bir Kurum: Talim ve Terbiye, Ankara 2008 (Baskıya Hazır Nüsha).

KOÇAK, Cemil, Umumi Müfettişlikler (1927-1952), İstanbul, İletişim Yayınları, 2003

ÖZTÜRK, Cemil, Atatürk Devri Öğretmen Yetiştirme Politikası, Ankara, Türk Tarih Kurumu Basımevi, 1996

ÖZTÜRK, Saygı, İsmet Paşa'nın Kürt Raporu, İstanbul, Doğan Kitap, 2007

PEHLIVANLI, Hamit, "Cumhuriyet'in İlk Yıllarından Günümüze Doğu ve Güneydoğu Anadolu'nun Meseleleri: Örnek Raporlar Işığında Karşılaştırmalı Bir Inceleme", Beşinci Askeri Tarih Semineri Bildirileri (Ístanbul 1995), Ankara 1996

YAZICI, Mustafa, Tanzimat'tan Bu Yana Millî Eğitim Bakanları Başbakanlar ve Atatürk (1839-1973), Ankara, Emel Matbaacılık, 1973. 